This study was supported by the Swedish Council for Planning and Co-ordination of Research (BP) and the Swedish Delegation for Social Research, Ministry of Health and Social Affairs (HK).

\section{References}

${ }^{1}$ Straus R. Alcohol abuse and physicians' responsibility. Arch Intern Med 1977;137:1513-5.

${ }^{2}$ Lieber CS. A public health strategy against alcoholism and its complications. Am 7 Med 1978;65:722-6.

${ }^{3}$ Selzer ML. The Michigan alcoholism screening test (MAST): the quest for a new diagnostic instrument. Am $\mathcal{F}$ Psychiatry 1971 ;127:1653-8.

4 Kristenson H, Trell E, Fex G, Hood B. Serum gamma-glutamyltransferase: statistical distribution in a middle-aged male population and evaluation of alcohol habits in individuals with elevated levels. Prev Med 1980;9:108-19.

5 Tibblin G. High blood pressure in men aged 50. Acta Med Scand (Suppl) $1967 ; 470$.

- Tibblin G. Alkohol som riskfaktor för sjukdom och död. Läkartidningen $1974 ; 71: 2053-5$.

7 Tibblin G, Wilhelmsen L, Werkö L. Risk factors for myocardial infarction and death due to ischaemic heart disease and other causes. Am f Cardiol $1975 ; 35: 514-22$.

8 Lannerstad O. Död och sjukdom bland medelålders män. Thesis. Studentlitteratur (Lund) 1978.
${ }^{9}$ US Secretary of Health, Education and Welfare. Second special report to the US Congress on alcohol and health. Washington: US Department of Health, Education and Welfare, 1974. (Preprint edition.)

10 Dyer RD, Stamler J, Paul O, et al. Alcohol consumption, cardiovascular risk factors and mortality in two Chicago epidemiologic studies. Circulation 1977;56:1067-74.

${ }^{11}$ Rosalki SB, Rao D. Serum gamma-glutamyltranspeptidase activity in alcoholism. Clin Chim Acta 1972;39:41-7.

12 Rollason JG, Pincherle G, Robinson D. Serum gamma-glutamyltranspeptidase in relation to alcohol consumption. Clin Chim Acta 1972;39:75-80.

${ }^{13}$ Wu A, Slavin G, Levi AJ. Elevated serum gamma-glutamyltransferase (transpeptidase) and histological liver damage in alcoholism. $\mathrm{Am} \mathcal{F}$ Gastroenterol 1976;65:318-23.

14 Whitehead TP, Clarke CA, Whitfield AGW. Biochemical and haematological markers of alcohol intake. Lancet $1978 ; \mathrm{i}: 978-81$.

${ }^{15}$ Whitfield JB, Hensley WJ, Bryden D, Gallagher H. Some laboratory correlates of drinking habits. Ann Clin Biochem 1978;15:297-303.

${ }^{16}$ Bagrel A, d'Houtard A, Gueguen R, Siest G. Relation between reported alcohol consumption and certain biological variables in an "unselected" population. Clin Chem $1979 ; 25: 1242-6$.

17 Kondo H, Hashida M, Momotani H. Serum gamma-glutamyltranspeptidase as a diagnostic aid in the periodic health examination. Sangyo Igaku 1976;1:95-100.

18 Beagelhole R, Foulkes MA, Prior IAM, Eyles EF. Cholesterol and mortality in New Zealand Maoris. Lancet $1980 ; 1: 285-7$.

(Accepted 6 March 1980)

\section{Summary and conclusions}

Twelve patients aged over 70 with primary hyperparathyroidism (persistent hypercalcaemia and raised serum parathyroid hormone concentrations) underwent parathyroidectomy, which was well tolerated by all. After operation serum calcium concentrations returned to normal and the commonest symptoms before operation (muscle weakness, malaise, and mild to severe dementia), although not related in severity to the degree of hypercalcaemia, improved. Mental function was greatly improved.

The findings suggest that primary hyperparathyroidism should be sought in any elderly patient with hypercalcaemia and that more such patients with the diagnosis should be considered for parathyroidectomy irrespective of age.

\section{Introduction}

Biochemical screening detects many cases of hyperparathyroidism that would otherwise go unrecognised. Most show no evidence of bone disease or renal disease. The commonest group of patients with hyperparathyroidism presenting at our

Queen Elizabeth Hospital, Birmingham B15 2TH

D A HEATH, $M B$, FRCP, reader, university department of medicine A D BARNES, MB, FRCS, consultant surgeon

\section{General Hospital, Birmingham B4 6NH}

A D WRIGHT, MB, MRCP, senior lecturer, university department of medicine G D OATES, MB, FRCs, consultant surgeon

N J DORRICOTT, MB, FRCs, consultant surgeon clinics complain of muscle weakness, tiredness, and general malaise. The next commonest group are patients who appear to be completely asymptomatic but in whom hypercalcaemia is found by chance during investigations for other problems. With the increased recognition of the disease, many elderly patients have been found to have hyperparathyroidism. In such patients the non-specific nature of the symptoms may readily be attributed to "aging," and the decision to operate may be difficult. We report our experience of parathyroidectomy in 12 patients aged 70 or over, which encourages us to recommend operations in symptomatic patients in this age group.

\section{Patients, methods, and results}

The table gives the details of the 12 patients. The commonest symptoms were muscle weakness, mental slowing, and decreased mobility. Before operation, three of the patients (cases 2, 7, and 8) were unable to manage at home and were awaiting long-term hospital care, while two others (cases 5 and 11) were able to live at home only because of considerable attention from relatives living in the same house. Another patient (case 6) had been transferred to sheltered accommodation before operation. In all 12 patients the hypercalcaemia was discovered during routine biochemical investigations for assessment of deteriorating physical state or for completely unrelated medical problems. Hyperparathyroidism was diagnosed when persistent hypercalcaemia was present with raised serum parathyroid hormone concentrations. No patient showed radiological evidence of the disease. At operation a single parathyroid adenoma was found in all cases except case 10, in which two adenomas were removed at separate operations. Successful removal of the adenomas was associated with rapid return of the serum calcium concentration to normal. The operation was well tolerated by all the patients, and no serious complications occurred. Only one patient (case 5) developed severe symptomatic hypocalcaemia. Although mild asymptomatic hypocalcaemia often occurred after operation, all patients eventually achieved normocalcaemia without long-term treatment with calcium supplements or vitamin D. 
Clinical characteristics, serum biochemical indices before operation (given as range of values, or as only value), and history in 12 elderly patients with primary hyperparathyroidism

\begin{tabular}{|c|c|c|c|c|c|c|c|c|}
\hline \multirow[b]{2}{*}{$\begin{array}{l}\text { Case } \\
\text { No }\end{array}$} & \multirow[b]{2}{*}{$\begin{array}{l}\text { Age } \\
\text { and sex }\end{array}$} & \multicolumn{5}{|c|}{ Biochemical indices } & \multicolumn{2}{|c|}{ History } \\
\hline & & $\begin{array}{l}\text { Calcium } \\
(\mathrm{mmol} 1)\end{array}$ & $\begin{array}{l}\text { Phosphate } \\
(\mathrm{mmol} \mathrm{1)}\end{array}$ & $\begin{array}{l}\text { Alkaline phosphatase } \\
\text { (KA units/dl) }\end{array}$ & $\begin{array}{c}\text { Urea } \\
(\mathrm{mmol} / \mathrm{l})\end{array}$ & $\begin{array}{c}\text { PTH } \\
(\mu \mathrm{g} / 1)\end{array}$ & Before operation & After operation \\
\hline 1 & $75, M$ & $3 \cdot 0-3 \cdot 4$ & $0 \cdot 5-0 \cdot 7$ & $7-13$ & $5 \cdot 5-7 \cdot 4$ & $1 \cdot 1^{*}$ & Diabetes mellitus, poor control. & Improved memory. More active. \\
\hline 2 & $73, \mathrm{M}$ & $4 \cdot 8$ & & $10-12$ & $11 \cdot 0-26 \cdot 0$ & $1 \cdot 1+$ & Poor memory. Muscle weakness & $\begin{array}{l}\text { No change in diabetic control } \\
\text { Complete recovery. Living at }\end{array}$ \\
\hline 3 & $71, \mathrm{~F}$ & $3 \cdot 0-3 \cdot 3$ & $0 \cdot 6$ & $11-18$ & $8 \cdot 1-10 \cdot 2$ & $3 \cdot 8^{*}$ & $\begin{array}{l}\text { Headache. Amnesia. Muscle } \\
\text { weakness. Difficulty in walking }\end{array}$ & $\begin{array}{l}\text { home } \\
\text { More alert and mobile. } \\
\text { No headaches }\end{array}$ \\
\hline 4 & $72, \mathrm{M}$ & $2 \cdot 6-3 \cdot 2$ & $0 \cdot 7-0 \cdot 8$ & $9-13$ & $6 \cdot 0-18 \cdot 0$ & $2 \cdot 2^{*}$ & weakness. Diliticusty in walking & $\begin{array}{l}\text { No headaches } \\
\text { Reduced insulin requirements }\end{array}$ \\
\hline 5 & $72, M$ & $3 \cdot 0-3 \cdot 5$ & 0.9 & $9-10$ & $11 \cdot 0-15 \cdot 0$ & $3 \cdot 3^{*}$ & $\begin{array}{l}\text { Slurred speech. Muscular } \\
\text { weakness. Vague aches and pains }\end{array}$ & $\begin{array}{l}\text { Improved muscle strength and } \\
\text { wellbeing }\end{array}$ \\
\hline 6 & $78, \mathrm{~F}$ & $2 \cdot 9-3 \cdot 0$ & $\begin{array}{l}0 \cdot 8 \\
-\end{array}$ & $47-55$ & $8 \cdot 9-19 \cdot 8$ & $3 \cdot 8+$ & $\begin{array}{l}\text { Muscle weakness. Agitation and } \\
\text { anxiety. Difficulty in walking }\end{array}$ & $\begin{array}{l}\text { Improved muscle strength and } \\
\text { wellbeing. More active. }\end{array}$ \\
\hline 7 & $83, \mathrm{~F}$ & $2 \cdot 6-2 \cdot 9$ & $0 \cdot 8-1 \cdot 1$ & $10-11$ & $8 \cdot 7-11 \cdot 1$ & $0.5 \dagger$ & $\begin{array}{l}\text { Muscle weakness. Progressive } \\
\text { dementia. Unmanageable at home }\end{array}$ & $\begin{array}{l}\text { Complete clearing of dementia. } \\
\text { Increased muscle strength. }\end{array}$ \\
\hline 8 & $70, \mathrm{~F}$ & $3 \cdot 0-3 \cdot 4$ & $2 \cdot 1-2 \cdot 4$ & $16-21$ & $26 \cdot 0-40 \cdot 0$ & $3.6+$ & $\begin{array}{l}\text { Dementia. Muscle weakness. } \\
\text { Unable to walk. Unmanageable } \\
\text { at home }\end{array}$ & $\begin{array}{l}\text { Considerable mental improvement } \\
\text { More mobile. Improvement in } \\
\text { wellbeing. Living at home }\end{array}$ \\
\hline 9 & $81, F$ & $2 \cdot 5-2 \cdot 7$ & 0.8 & $9-13$ & $5 \cdot 9-8 \cdot 7$ & $0.8 \dagger$ & $\begin{array}{l}\text { Muscle weakness. Difficulty in } \\
\text { walking }\end{array}$ & $\begin{array}{l}\text { More mobile. Improvement in } \\
\text { wellbeing }\end{array}$ \\
\hline 10 & $70, \mathrm{~F}$ & $2 \cdot 7-2 \cdot 9$ & $0 \cdot 8-1 \cdot 0$ & $6-10$ & $4 \cdot 7-6 \cdot 7$ & $1.5 \dagger$ & $\begin{array}{l}\text { Profound tiredness. Muscle } \\
\text { weakness }\end{array}$ & $\begin{array}{l}\text { Condition much improved. More } \\
\text { energetic and active }\end{array}$ \\
\hline 11 & $75, \mathrm{~F}$ & $2 \cdot 6-2 \cdot 7$ & $1 \cdot 1$ & $12-16$ & $15 \cdot 4-20 \cdot 3$ & $4 \cdot 0 \dagger$ & Progressive dementia for one year & Considerable improvement in \\
\hline 12 & $76, \mathrm{~F}$ & $2 \cdot 9-3 \cdot 0$ & & $12-16$ & $5 \cdot 4-7 \cdot 8$ & $1.8 \dagger$ & $\begin{array}{l}\text { Thirst. Muscle weakness. Renal } \\
\text { stone and myocardial infarction }\end{array}$ & $\begin{array}{l}\text { Condition much improved. } \\
\text { More active }\end{array}$ \\
\hline
\end{tabular}

-Assay performed by supraregional assay service-normal values $<1.0 \mu \mathrm{g} / 1$

After operation the symptoms improved in 11 of the 12 patients. Most reported considerable improvement in wellbeing. One patient (case 10) reported no improvement after her first neck exploration despite initially being unaware that her calcium concentration had not returned to normal. After removal of the second adenoma her calcium concentration returned to normal, and she noted a definite improvement in wellbeing. All 10 patients with muscle weakness improved, resulting in increased mobility and activity. Mental function was considerably improved. All three patients with severe mental impairment improved, although one (case 11) continued to have some impairment of both short-term and long-term memory.

\section{Discussion}

Hypercalcaemia is usually due to either primary hyperparathyroidism or malignancy. We find that when due to malignancy it is associated with disease that is relatively obvious on examination; in our assay serum parathyroid hormone concentrations are usually undetectable.

Hyperparathyroidism was diagnosed easily in these patients once the hypercalcaemia was detected, owing to the absence of obvious malignancy and the presence of raised hormone concentrations. The main difficulty was in deciding whether the patients would benefit from parathyroidectomy. In one patient with severe hypercalcaemia (case 2) the decision was easy, but in six of the 12 patients the serum calcium concentration never exceeded $3.0 \mathrm{mmol} / 1(12 \mathrm{mg} / 100 \mathrm{ml})$. There was poor correlation between the severity of symptoms and degree of hypercalcaemia. One of the most impressive clinical improvements was seen in the patient with the mildest hypercalcaemia (case 7). The hypercalcaemia was initially thought to be unrelated to her progressive dementia, and a conservative policy was followed for two years. Only when she became impossible to manage at home and after considerable prompting from her general practitioner was an operation performed with dramatic beneficial results; because of this an operation was recommended in case 11 , in which the severe dementia seemed disproportionate to the mild hypercalcaemia. Although recovery of mental function was not complete it was sufficient to enable her husband to have normal conversations with her for the first time in over a year. This recovery and her improved mobility removed the immediate need for consideration of long-term hospital care.

Apart from the 12 patients reported on here we have seen several others in this age group with similar biochemical results and apparently few or no symptoms of the disease. Whether such patients will require operations in the future remains to be seen.

Most large published studies of hyperparathyroidism do not include a high proportion of elderly patients. Pyrah et al, ${ }^{1}$ reviewing available reports, noted that only 18 out of 890 patients were aged 70 or over. These elderly patients were predominantly women. More recent reports, however, have begun to show an increased proportion of elderly patients, which presumably reflects the increased use of biochemical screening. In a series of 147 asymptomatic patients, $21(14 \%)$ were aged 70 or over. ${ }^{2}$ Similarly, Freidin ${ }^{3}$ reported that nine out of 84 patients were aged 70 or over. Of more importance is the report by Peskin et al, ${ }^{4}$ in which 17 of the last 40 consecutive cases of hyperparathyroidism proved by operation were over 69 , and 12 of them were women. Our findings confirm this high proportion of elderly female patients with hyperparathyroidism.

Few reports on the results of operations for hyperparathyroidism have been concerned specifically with elderly patients. Riddick ${ }^{5}$ reported on 19 patients over 59 years who were treated by operation, but only four were over 69 . Biochemical screening was not then widely available and, not surprisingly, most patients had either bone disease or renal stones. Ten of the 19 also had lethargy, weakness, or mental changes, which, on the whole, improved rapidly after operation. Davidson et al ${ }^{6}$ described a single patient, aged 86 , who was successfully operated on and whose symptoms were weight loss, weakness, difficulty in swallowing, nausea, and vomiting. The findings most similar to ours were those of Alveryd, et al, ${ }^{7}$ who described 30 patients aged over 70 treated by operation for hyperparathyroidism. Neuromuscular symptoms, fatigue, or mental symptoms predominated in half of the patients. Seven of the eight patients with neuromuscular symptoms improved after operation, as did two of the three patients with extreme fatigue. The three patients with severe mental symptoms did not improve. Peskin et al ${ }^{4}$ further emphasised the prevalence of mental symptoms in their 17 elderly patients, in whom renal stones were also uncommon. Response to operation in their patients was excellent: all showed improved mentation and wellbeing and were less subject to fatigue. Operative mortality was nil and morbidity low.

Successful treatment by operation in such patients, who are usually frail, is helped by an expeditious atraumatic exploration of the neck by surgeons with considerable, regular experience of the operation. A search is made of the areas where adenomas 
commonly occur in an attempt to identify an adenoma and at least one normal gland. Virtually all the adenomas are accessible through a cervical incision, and the sternum should not be split at the primary exploration. The surgical task is much facilitated by working with an anaesthetist who is fully aware of the requirements of the operation. There should be a clear airway, controlled ventilation, and normotension. Using these guidelines we find that the operation is well tolerated by these elderly patients, all of whom have had an uneventful postoperative course. There have been no deaths, and the improvement in wellbeing and activity after operation has been striking.

These results encourage us to consider more patients for operation irrespective of age provided that they have symptoms. Hypercalcaemia, however mild, should be investigated, as a preoperative diagnosis of hyperparathyroidism can now usually be made with considerable accuracy. Other reports support our findings that muscle weakness, lethargy, and general malaise respond well to correction of the hyperparathyroidism, but our present findings suggest that improvement in dementia may be more common than other reports indicate.

Although the improvements in our patients were predominantly subjective, they were enough to prevent three of the patients from being admitted for long-term hospital care. The improved mobility also allowed several of them to manage shopping and other domestic duties. As more and more elderly patients are found to have hyperparathyroidism it will be important to try to devise more objective methods of assessing their response to treatment.

We thank Dr M Waite for permission to include case 11 .

\section{References}

${ }^{1}$ Pyrah LN, Hodgkinson A, Anderson CK. Primary hyperparathyroidism. Br F Surg 1966;53:245-316.

2 Purnell DC, Smith LH, Scholz DA, Elveback LP, Arnaud CD. Primary hyperparathyroidism: a prospective clinical study. Am F Med 1971;50: $670-8$.

${ }^{3}$ Freidin J. Twenty years' experience with parathyroid exploration. Aust NZ F Surg 1978;48:261-9.

${ }^{4}$ Peskin GW, Greenburg AG, Saik RP. Expanding indications for early parathyroidectomy in the elderly female. Am $\mathcal{f}$ Surg 1978;136:45-8.

5 Riddick FA Jr. Primary hyperparathyroidism in the aged. Geriatrics 1967;22:94-8.

${ }^{6}$ Davidson ET, Johnson JH, Collins JP. Age and primary hyperparathyroidism. South Med $\mathcal{F} 1971 ; 64: 760-1$.

7 Alveryd A, Boström $\mathrm{H}$. Wengle B, Wester PO. Indications for surgery in the elderly patient with primary hyperparathyroidism. Acta Chir Scand 1976;142:491-4.

(Accepted 6 March 1980)

\title{
Cutaneous microcirculation in systemic sclerosis and response to intra-arterial reserpine
}

\author{
K HAAVIK NILSEN, MALCOLM I V JAYSON
}

\section{Summary and conclusions}

The cutaneous microcirculation in the hand was measured in 23 patients with systemic sclerosis, 19 with Raynaud's phenomenon and four without Raynaud's phenomenon, and 20 controls. The patients with Raynaud's phenomenon had a reduced basal blood flow and an exaggerated further reduction on local cold stimulation, though both were normal in patients without Raynaud's phenomenon. Reflex-induced vascular changes by cold stimulation of the contralateral hand showed no differences between the three groups. The blood flows were similar in the affected skin of the anterior chest wall in four patients with systemic sclerosis and peripheral Raynaud's phenomenon and matched controls. In the seven most severely affected patients $1 \mathrm{mg}$ of intra-arterial reserpine produced a prompt improvement in the cutaneous microcirculation which usually lasted one to three weeks but occasionally much longer. By judicious use of repeated injection guided by measurements of the microcirculation it was possible to heal indolent ulcers of the fingers.

The results indicate that vascular changes are common in systemic sclerosis but are not fundamental in the

\footnotetext{
Rheumatic Diseases Centre, University of Manchester, Hope Hospital, Salford M6 8HD

K HAAVIK NILSEN, MD, FRACP, consultant and senior lecturer in rheumatology (present address: Department of Rheumatology, Betanien Hospital, 3700 Skien, Norway)

MALCOLM I V JAYSON, MD, FRCP, professor of rheumatology
}

pathogenesis of the disease. More probably there is a general soft tissue abnormality that usually but not necessarily affects the vessels.

\section{Introduction}

The clinical features of systemic sclerosis are due to a combination of fibrosis and induration of tissue, vascular obstruction, and ischaemic atrophy. In particular, Raynaud's phenomenon and widespread vessel changes occur in various organ systems. In patients with severe Raynaud's phenomenon peripheral ischaemia leads to gangrene of the digits. There is debate over whether these vascular changes are fundamental in the pathogenesis of systemic sclerosis and initiate the florid tissue changes or whether there is a generalised tissue abnormality around and including the blood vessel walls which causes vascular obstruction. We compared these hypotheses by measuring the microcirculation within the skin and the changes that occur during exposure to cold in controls and patients with progressive systemic sclerosis with and without Raynaud's phenomenon. In those patients with severe Raynaud's phenomenon and peripheral ischaemia the responses of the microcirculation to intra-arterial reserpine were recorded.

\section{Patients and methods}

Twenty controls and 23 patients with systemic sclerosis with typical cutaneous features confirmed by biopsy (19 with and four without Raynaud's phenomenon) were studied. The patients with systemic sclerosis showed varying degrees of visceral changes. In particular, the four without Raynaud's phenomenon all had 